\title{
Journal of Engineering and Technology Management
}

\section{Exploring the impact of innovation implementation on supply chain configuration}

Article information:

Post-Print version

To cite this document:

Sabri Y., Micheli G.J.L., Nuur C. (2018) "Exploring the impact of innovation implementation on supply chain configuration", Journal of Engineering and Technology management, in press.

Permanent link to this document: https://doi.org/10.1016/j.jengtecman.2018.06.001

Acknowledgements

This paper is produced as part of EMJD Programme European Doctorate in Industrial Management (EDIM) funded by the European Commission, Erasmus Mundus Action 1. 


\title{
Exploring the impact of innovation
}

\section{implementation on supply chain configuration}

\author{
Yasmine Sabri ${ }^{\mathrm{a}}, *$, Guido J.L. Micheli ${ }^{\mathrm{a}}$, Cali Nuur ${ }^{\mathrm{b}}$ \\ a Department of Management, Economics and Industrial Engineering, Politecnico di Milano, Milan, Italy \\ b Department of Industrial Economics and Management, Royal Institute of Technology, Stockholm, Sweden
}

\section{Corresponding author: Yasmine Sabri*}

Department of Management, Economics and Industrial Engineering, Politecnico di Milano,

Via Raffaele Lambruschini, 4/B, 20156 Milano, Italy

yasminesabri.hassan@polimi.it

\begin{abstract}
Considering the foreseen digital transformation and rapid dissemination of technological innovations, this paper investigates what happens along the supply chain (SC) when process and product innovation practices are implemented. The research examines the SC strategy and configuration of four product families; it considers the configuration to incorporate the whole range of SC functions and relationships.

The paper addresses the little attention paid to the process innovation dimension in SC literature, and develops a framework capturing the dynamics between innovation implementation and configuration decisions and settings. The provided analyses guide practitioners on better management of innovation implementation along the supply chain.
\end{abstract}

Keywords: supply chain innovation, supply chain transformation, configuration, product innovation, process innovation. 


\section{Introduction}

In the era of digital transformation, supply chains will have to accommodate an expected rapid dissemination of technological innovations (Goldsby and Zinn, 2016; MacCarthy et al., 2016). The recent technological developments can alter the landscape of the supply chain and its configuration; as such, the design of the physical, financial and information flows is expected to be revolutionised (Kearney and WHU, 2015).

Innovation is addressed extensively in the supply chain domain (e.g. Bellamy et al., 2014; Zimmerman et al., 2016); however, further attention is still needed to examine the challenges that span the whole supply chain when firms implement innovation - that is, to investigate the entire supply chain configuration, as well as the relationships among the supply chain members (Arlbjørn et al., 2011; Arlbjørn and Paulraj, 2013). The extant literature indicates that most businesses do not change the configuration of their supply chains when they start to implement innovation practices (Arlbjørn et al., 2011), which signals a misfit between the configuration of supply chains and their environment and strategy (i.e. environment-structure-strategy misfit). A better understanding of the impact of innovation implementation, from a holistic perspective, is therefore needed. By doing so, it will be possible to mitigate any risks that might propagate along the supply chain. Furthermore, such a holistic perspective will provide a more realistic analysis of the tangible impact of innovation implementation, which can lead to better management of innovation along the different phases of the supply chain.

The process innovation dimension is emerging as an interesting research topic due to the increased diffusion of digitalisation and an expected surge in process innovation (e.g. additive manufacturing, Industry 4.0 tools and AGV-managed warehouses) (Kearney and WHU, 2015; GCI and Capgemini, 2016). There is a substantial number of scholarly publications on the 
interplay between the various aspects of innovation and the supply chain (Lo and Power, 2010; Pero et al., 2010; Stavrulaki and Davis, 2010; Ülkü and Schmidt, 2011; Pashaei and Olhager, 2015); however, these studies mostly address the product dimension (i.e. new product development/launch, product characteristics and design). So far, the process innovation and its implications for the supply chain have been under-researched.

The relationship between innovation implementation and supply chain configuration can be better interpreted by embracing the concepts of contingency theory, which suggest that the peculiarities of a firm's internal and external contextual environments need to be considered in its design, so as to improve its performance (i.e. to establish environment-structure-strategy fit) (Drazin and Van de Ven, 1985). This paper considers the implementation of process and product innovation practices as contextual factors, whose impact on the configuration and performance is investigated. The present research examines what happens along the supply chain when a firm decides to implement an innovation, through investigating the interplay between innovation practices' implementation and supply chain configuration - that is, investigating the aspects related to operations, supplier selection, supply and distribution network design, transportation mode, facility globalisation/localisation, sourcing decisions, and collaboration and information sharing (Chandra and Grabis, 2007; Chopra and Meindl, 2007; Farahani et al., 2014; Melnyk et al., 2014).

\section{Theoretical background}

\subsection{Definitions of innovation}

Innovation is regarded as a "complex and multi-dimensional phenomenon" (Adams, 2003, p.4), and its literature involves various research disciplines and definitions largely based on the 
classical definition of Schumpeter (1939) - i.e. that innovation entails developing new products and new forms of organisational structure, opening up new markets, creating new production functions and finding new sources of raw material. Drucker (1985) argues that innovation is the main function of entrepreneurship, whether by using new resources or developing existing knowledge resources to create what he describes as wealth at the industrial or national levels. Rogers (1998) defines innovation as the activities and changes performed to produce new or improved products or processes within a firm to improve its performance. The notion of disruptive innovation was introduced by Christensen (1997) and is related to igniting growth and creating new markets.

The conceptualisation of innovation is investigated in a number of studies - for example, the innovation typology developed in Garcia and Calantone (2002). Further categorisation can be performed depending on the range or influence of innovation activities. Classical innovation taxonomies are related to the application context-for example, product vs. process innovation (Blaug, 1963), or are based on the novelty of the innovation-for example, radical vs. incremental, technical vs. administrative (Gopalakrishnan and Damanpour, 1997). Innovation can also be considered as architectural, niche, regular, revolutionary (Abernathy and Clark, 1985), or as sustaining, evolutionary, disruptive (Christensen, 1997). The outlined discussion reveals that the innovation field of study is multifaceted and encompasses many dimensions. A synthesis of innovation practices, contexts and novelties is presented in Table 1.

This paper is concerned with the implementation phase of the innovation process. Our interest is in the impact of innovation practices' implementation within the boundaries of the supply chain. The authors therefore embrace the dimensions that are relevant to supply chain management, presented in Table 1, wherein innovation is considered to deal with introducing 
new products to the market (i.e. new product development), whether these products are exploiting breakthrough ideas (i.e. radical innovations) or existing products and processes (i.e. incremental innovation/continuous improvement).

\section{-- Insert Table 1 around here --}

\subsection{Supply chain configuration}

The notion of configuration emerges from organisational and strategic management research (see, for example, Mintezberg, 1979), in which configuration is defined as a "the degree to which an organisation's elements are orchestrated and connected by a single theme" (Miller, 1996, p.509) or as a "constellation of interconnected elements" (Fiss et al., 2013, p.1).

In the supply chain domain, configurations are predominantly conceptualised in terms of structural elements, such as the size of companies/entities (nodes); where these nodes are located geographically; how raw material is provided (i.e. the supply network design); and how the final product reaches the final customers (i.e. distribution channel design) (Chandra and Grabis, 2007; Chopra and Meindl, 2007).

A supply chain's main role is to efficiently and effectively manage the flows of products, services, finances and information from the source to the end customer, with an ultimate goal of creating added value and increased customer satisfaction (Harland, 1996; Ellram and Cooper, 2014). The configuration is then concerned with integrating the operations and the strategy of a single firm with those of the other supply chain members. The settings of supply chain configuration are therefore entangled with almost all operational and strategic decisions related to supplier selection, supply network design, transportation mode, distribution network design, design of raw material flows, facility globalisation/localisation, outsourcing/sourcing, and 
collaboration and information sharing (Chandra and Grabis, 2007; Chopra and Meindl, 2007; Melnyk et al., 2014). Miller (1996) emphasises that configurations are the essence of the strategy. This paper therefore extends the concept of supply chain configuration to include supply chain strategy in addition to the traditional structural view of the configuration.

In the literature review conducted here, we categorise supply chain configuration research in three main dimensions: (1) studies clustering supply chain configurations into defined archetypes; (2) studies clustering supply chain structures into collective patterns; and (3) studies maximising/minimising an objective-for instance, maximising performance, minimising distribution costs or maximising vertical integration.

Studies in the first group, clustering supply chain configuration into archetypes, combine various configurations based on the relationships between supply chain members. This group includes the work of Cagliano et al. (2008), who identify various configurations of global and local sourcing and distribution networks. Caniato et al. (2013) identify four archetypes-locals, shoppers, barons and globals — based on their level of outsourcing. Studies in the second group, clustering supply chain structures into patterns, extend production philosophies to supply chain. Farahani et al. (2014) classify supply chain configurations as lean, agile/responsive, green and sustainable. Lee (2002) and Manuj and Mentzer (2008) classify supply chains as efficient, responsive, risk hedging and agile. In the same vein, Aitken et al. (2005) identify supply chains as lean, agile and leagile, while Chi et al. (2009) propose three structures: lean, agile and hybrid. Studies in the third group, maximising/minimising an objective, presented the most prevalent way of considering different supply chain configurations and designs. For instance, Persson and Olhager (2002) present a model for optimising performance parameters such as quality, lead time and costs. Additionally, a significant number of studies have 
investigated configuration through the lens of operational research. For instance, Amini and Li (2011) present an optimisation model for supply chain configuration and new product diffusion, while Amin and Zhang (2012) present an optimisation model for supplier selection and maximising profit in closed-loop supply chains.

\subsection{Innovation practices' implementation in the supply chain}

The extant literature (e.g. Zhu et al., 2012; Bellamy et al., 2014; Zimmermann et al., 2016) investigates various innovation issues and their links to supply chain aspects. The implementation of innovation practices affects supply chain structure and can be employed as a means of supply chain reengineering (Blackhurst et al., 2005). It also affects supply chain performance in terms of direct production costs and overheads, delivery times and inventory levels (Crippa et al., 2010).

The implementation of innovation practices is considered a key factor in supply chain management. Firms need to cope with the introduction of technological innovations (e.g. augmented reality, Internet of Things and additive manufacturing), which requires a mind shift in how the supply chain is configured and how its functions will be managed. Marsillac and Roh (2014) suggest that product innovation is usually accompanied by process innovation, since product changes/modifications require that the process of delivering the product must also undergo changes. Marsillac and Roh (2014) present the case of a firm that had to change its supply configuration because it introduced new products and modified its raw materials. In contrast, the findings of Arlbjørn et al. (2011) indicate that despite the extensive implementation of innovation practices along the supply chain, few businesses make changes to the structure of their supply chain network. 
Some researchers consider the decisions regarding innovation practices to be among the main decisions in designing/redesigning the supply chain. Fisher (1997) proposes configuring the supply chain based on the level of product innovativeness. Therefore, the first step in configuring a supply chain is to determine whether the product is innovative or functional. Similarly, Burgess and Gules (1998) investigate supply network design (supplier relationships) when firms embark on using advanced technologies. Further studies (e.g. Gan and Grunow, 2013) explore the differences in designing supply chains based on whether or not they deliver an innovative product.

Implementation of innovation practices within supply chain boundaries can be regarded as a business network (or cluster) capability (Arlbjørn and Paulraj, 2013). A firm that is able to innovate should be equally able to manage complex supply chains to deliver its innovative products successfully to the market (Gan and Grunow, 2013). Some studies (e.g. Holahan et al., 2014) suggest that new product development is a core competence or capability of a firm. This line of thinking draws attention to the adoption of innovation practices within firms to increase their market share, thus increasing their profitability. However, can supply chains be considered an 'innovation cluster', albeit a virtual one? According to Choi et al. (2013), the answer might be yes. Choi et al. (2013, p.4511) define innovation networks or clusters as "geographically close groups of interconnected companies and associated institutions in a particular field, linked by common technologies and skills across horizontal or vertical supply networks"; this definition overlaps with the characteristics of supply chains, apart from geographical proximity.

Innovation practices' implementation is often linked to product and process characteristics. The idea of integrating the latter two with supply chain structures to achieve superior 
performance emerged in the seminal work of Fine $(1998,2000)$, proposing the 3D-concurrent engineering concept, where there is an overlap of responsibilities between supply chain design, product specification and process planning. Fine (1998) also proposed the concurrency model incorporating product and process design (technology), process manufacturing systems and logistics management (focus), and supply chain structure and product architecture (architecture). Fixson (2005) expanded Fine's $(1998,2000)$ work by proposing a framework that maps the linkages between process, product and supply chain decision-making. Three product features affecting the supply chain (i.e. modularity, variety and innovativeness) were examined by Pero et al. (2010), who identify product innovativeness, rather than variety or modularity, as a key supply chain influencer. Prior literature highlights the relationship between certain product characteristics and the supply chain configuration. For instance, Stavrulaki and Davis (2010) distinguish between high/low volume and high/low demand uncertainty. They suggest that for products with high volume and low demand uncertainty, the supply chain should be lean, while products with low volume and high demand uncertainty need more flexible processes and their supply chains should be designed to be agile accordingly. They make another distinction in the process dimension, considering four processes: build to stock, assemble to order, make to order and design to order.

In contrast, Ülkü and Schmidt (2011) report that product architecture is dependent on supply chain configuration (in terms of make vs. buy decisions). Similarly, Lo and Power (2010) reject Fisher's (1997) propositions that supply chain strategy is linked to product nature, drawing their conclusions from a questionnaire-based study of Australian manufacturers. The findings of Lo and Power (2010) and Ülkü and Schmidt (2011) are insightful, as they capture the lack of a synchronised design of the product-process-supply chain in some industries. Ülkü and Schmidt 
(2011) propose designing the supply chain first then deciding on the product characteristics, a conclusion echoed in Pashaei and Olhager's (2015) systematic review, which highlights that most studies focus on how product characteristics affect supply chain, while the reverse relationship is little researched. A synthesis of the innovation practices addressed in the supply chain literature and their relationships with various supply chain functions is presented in Table 2.

\section{-- Insert Table 2 around here --}

\subsection{Contextualisation of supply chain configurations}

Contingency theory suggests that for firms to achieve greater performance, they must establish a fit between their structures and their internal and external environments (Drazin and Van de Ven, 1985). To extend this concept to the supply chain level, a comprehensive investigation of the possible contextual factors that represent internal and external supply chain environments is needed (Flynn et al., 2010).

Supply chain contingency studies investigate the role of contextual factors and their impact on performance. Brandon-Jones et al. (2014) apply a contingent resource-based view in studying how organisations develop supply chain resilience and robustness, considering geographical dispersion, sales complexity, differentiation and delivery complexity as the main contextual factors. Similarly, Gimenez et al.'s (2012) study of the mechanisms linking supply chain integration and performance finds that the relationships between these mechanisms give different results in different contexts. Van der Vaart et al. (2012) highlight the important role of contextual factors in supply chain integration studies; their findings agree with those of Gimenez et al. (2012) in considering supply chain complexity a contextual factor. 
Contingency theory draws attention to the fit between supply chain structures and their environments (Drazin and Van de Ven, 1985; Fry and Smith, 1987; Venkatraman, 1989). The role of contextual factors is addressed by Sousa and Voss (2008), who confirm that supply chain practices are context-dependent. Moreover, the work of Chi et al. (2009) and Skipworth et al. (2015) provides empirical evidence supporting the argument that the alignment of various supply chain-specific practices, such as customer relations management, supplier selection, collaboration and information sharing, has an impact on improving performance and can be employed to boost companies' competitive advantage. This research clearly emphasises the importance of achieving a fit between supply chain configuration settings and contextual factors in order to achieve superior performance.

The contextual factors usually addressed in literature are company size, country of origin, location, industry type, market characteristics, product lifecycle and characteristics, and process complexity. In addition, there are a few factors not conventionally addressed in prior literature, such as environmental aspects and organisational structure (Ebben and Johnson, 2005; Melo et al., 2009; Jayaram et al., 2010; Zhang et al., 2012; Tsinopoulos and Mena, 2015). Zhang et al. (2012) suggest that industry type is among the main contextual factors, whilst Tsinopoulos and Mena (2015) propose that product variety and demand variability be considered in the supply chain contextual environment. Lau (2014) finds that product newness as a contextual factor positively affects new product development as well as supplier integration. It is worth noting that in a few studies (e.g. Harland et al., 2004), supply chain structure is itself considered a contextual factor.

For the sake of this research, product and process innovation practices' implementation is considered in terms of contextual factors, examined in greater detail in the next section. 


\section{Methodology}

\subsection{Research scope}

In light of the above theoretical discussion, this paper focuses on the relationship between innovation practices' implementation and supply chain configuration. Specifically, the idea is that the innovation phases are situated within the generic supply chain phases of plan, source, make, deliver and return. The main elements of the research (i.e. the variables to be addressed in this research) are operationalised as follows.

- Supply chain configuration (structure)

- Localisation/globalisation

- Supplier selection and supply network design

- Operations management tools and production practices

- Transportation mode and distribution network design

- Supply chain strategy (strategy)

- Group strategy

- Decision-making

- Innovation practices’ implementation (environment)

- Related to products: introducing new products (i.e. new product development), product portfolio renewal, product restyling and product redesign 
- Related to process: continuous improvement practices, process re-engineering, improvement projects for existing processes, and increasing production line efficiencies

These outlined elements guided the research team in identifying the case selection criteria and the data collection process, as well as in identifying the research delimitations and addressing the focus in the data analysis phase.

\subsection{Research design}

A case study methodology is considered appropriate for this paper. The importance of adopting a case-based methodology in contingency research is reiterated by Sousa and Voss (2008), as they suggest it is useful for theory building, and it better advances our knowledge when building explanations of the observations.

A case study methodology helps in exploring and describing real-life phenomena (Yin, 2014), as it is an ideal methodology for answering 'how' and 'why' questions (Rowley, 2002) and taking into account the associated contextual factors (Baxter and Jack, 2008). Case study can usually be used for theory generation, testing or elaboration; as it provides in-depth analysis of the context, variables and their relationships (Ketokivi and Choi, 2014).

This research follows a case study approach as the most appropriate research methodology to provide an in-depth interpretation of the relationship between innovation practices' implementation and supply chain configuration settings and decisions, a topic not extensively researched thus far. Employing case-based research presents an opportunity to extend the literature and engage in theory generation. Moreover, the case study approach allows the research team access to the actual decision-makers behind the existing supply chain configurations, providing a deeper understanding of the motivations underlying many of the 
configuration settings, which would have been very challenging had a quantitative approach been adopted. This research is based on a case study performed simultaneously in Sweden and Italy.

\subsection{Case selection}

Given the context-dependency of supply chains, and for research rigour, the authors followed the guidelines of Patton (1990) and Flyvbjerg (2011) in selecting cases with maximum variation - i.e. cases that display diversity in their characteristics — so as to provide richness in exposure and coverage, facilitating the identification of patterns of uniqueness. The authors sought firms representing various contextual factors (e.g. belonging to different industry sectors and implementing process and/or product innovation) and with varied product portfolios (i.e. product families) whose products and processes have varied characteristics. We wanted to study firms with different supply chain configuration settings, with global supply, production and distribution networks. Based on these criteria, and considering geographical proximity to the research team, the authors identified two corporate groups comprising ten subsidiaries with headquarters in Italy and Sweden, having different management styles and business cultures. One of the corporate groups is a leading manufacturer of high-technology engineered tools; the other is a leading manufacturer in the health and personal care sector.

\subsection{Data collection and analysis}

The data were collected through face-to-face and online (Skype) unstructured and semistructured interviews with key supply chain managers at the two corporate groups. Each interview was entirely conducted in the English language by at least two researchers, one being a senior researcher. The research team identified the respondents based on their deep involvement in the supply chain area for all products in the corporate groups and their vast 
professional experience of supply chain management. This research investigates the entire supply chain; thus, the primary criterion for identifying the respondents was focused on identifying key informants who can oversee the whole range of supply chain functions and relationships. As such, every key informant is involved in strategising and implementing innovation practices on a group level, and all supply chain information from the different product families has to be reported to this key informant.

In the light of the above, two key informants in groups A and B were identified. In corporate group $\mathrm{B}$, the research team held an initial interview to explain the research objectives with the group's R\&D General Manager, whose function is to set the group's strategic R\&D initiatives. Based on this meeting, the key informant was identified as the group's Vice President for Supply Chain Management. Group A's key informant was identified following email correspondences with their management team as the group's Head of Supply Chain Planning and CRM.

To ensure a complete dataset, the authors posed open-ended questions on innovation practices' implementation, product and process characteristics, performance indicators and supply chain configuration settings (e.g. number of companies in the supply chain, size and physical location, and supplier and distributor network design). A predefined preliminary questionnaire was sent to the respondents before the first interview, which was complemented by additional revised questions during the subsequent rounds of interviews. To ensure analytical accuracy, all interviews were audio recorded and afterwards transcribed by the research team. In total, the interviews in this study yielded around 11 interview hours, each interview lasting 45-75 minutes. Moreover, the authors conducted four field visits to the facilities of groups A and B during which field observations were recorded in the authors' research notes. Email and 
telephone correspondence was used for minor clarifications, and at a later stage to validate the analysis. The full case study protocol is available upon request.

Data were collected at the product family/brand level-i.e. three product family supply chains from group A and a generic supply chain from group B. The data collected were complemented by rich secondary data found in internal company documents (i.e. internal documentation related to supplier selection and evaluation and to distribution design), annual reports (2014/2015) and group websites. This helped us double-check the data retrieved from the interviews.

The unit of analysis is the physical supply chain; every product family that has a distinct supply chain represents a case. After the data gathering phase, a structured coding database was developed from the transcriptions. All transcribed interviews and secondary data were coded according to Saldaňa's (2012) guidelines for coding with patterns. Coding was performed in multiple rounds: open codes were identified from the raw data first, this being followed by inferential coding (Miles and Huberman, 1994). In this paper, patterns of similarity/difference, frequency/sequence and correspondence were coded. Codes were grouped into subcategories in a first round and into categories in a second round. Based on this categorisation, the authors formulated themes related to each category (high-level abstract concepts), leading to our interpretation of the categories and their relations relationships (presented in section 5).

\subsection{Validity and reliability}

The validity of case study findings depends on building constructs without premisconceptions. Internal validity refers to the logical validity of the relationships between the variables and results. This was ensured by grounding the research in a literature review that was used to develop a research framework depicting the potential relationships between innovation 
implementation and supply chain settings, and at a later stage by comparing the patterns of results. The paper follows Yin's (2014) recommendation to seek multiple sources of data: the authors conducted multiple rounds of interviews with a key informant in each corporate group. Moreover, the interview data were further triangulated against secondary data sources such as internal company documents, annual reports and websites.

External validity refers to generalisability. Although case study methodology does not allow for statistical generalisability, it does allow for analytical generalisability, so the replication rationale is usually adopted. This paper also adopts this rationale by conducting semi-structured and unstructured interviews in two corporate groups having multiple supply chains for multiple product families. In addition, the paper establishes a chain of evidence extracted from the data through rigorous analysis of the structured coding database as well as through cross-checking with members of the author's extended research group. To avoid any misalignment in the views on data analysis, the research team was in continuous communication with the key informants, resulting in no detected misalignments. Reliability is ensured by following a rigorous interview protocol (described in the data collection and analysis section) so as to minimise errors and confirm the reliability of the data analysis (Voss et al., 2002; Gibbert and Ruigrok, 2010; Yin, 2014). To ensure the rigour of the interview protocol, the research team made sure that any topic discussed in the semi-structured and unstructured interviews fell strictly within the borders of the topics identified earlier in the protocol.

\section{4. $\quad$ Findings and case description}

\subsection{Corporate groups under investigation}


The parent companies in groups $\mathrm{A}$ and $\mathrm{B}$ are leading manufacturers in their industrial sectors. Group A comprises six subsidiaries in the healthcare, childcare and personal care product sectors. Present in 24 countries (15 in Europe, four in Brazil, Russia, India and China (BRIC) countries, and the rest in North and South America), it has around 400 points of sale worldwide. It has recently undergone major changes in its management culture and top management positions, transitioning from a family-owned and managed company to a more formally structured and professionally managed corporate group. Recently, group A introduced certain organisational changes, resulting in the initiation of performance improvement projects. The new management of group A has focused on improving supply chain performance, mainly in terms of cost reductions and inventory management.

Group B is a structured publicly listed shareholders corporate group of four companies. The subsidiary where the interviews took place was selected because sales of its product family generate around 55 per cent of the group's operating profits and represent around 35 per cent of the invoiced business of the whole group. The management style in group B is well established and stable. However, the group has recently expanded its business and acquired competing brands, resulting in a situation in which some of the newly acquired brands now have supply chain functions separately managed from those of the parent company. Table 3 presents a description of the cases.

\section{-- Insert Table 3 around here --}

\subsection{Supply chain configuration}


Despite the different characteristics of their processes and products, in some ways the two groups display similar supply chain configuration settings. Table 4 outlines the configuration settings of the studied supply chains in the two groups. Both groups have suppliers, production units, sales branches and warehouses mainly concentrated in Europe, but with a strong presence in Asia and North America. Their collaboration activities differ as the groups' supply chain strategies differ.

\section{-- Insert Table 4 around here -}

Figures 1 and 2 present the footprints of the groups' supply chains, encompassing supply, production, distribution, central warehousing and sales. Group A focuses on global raw material supply and centralised warehousing policies; its sales follow B2C and B2B strategies, which are managed by reviewing supplier performance every six months and negotiating until agreements are reached. Group B focuses on localised supply from Europe and multiple distribution centres; its sales strategy is mostly B2C.

-- Insert Figure 1 around here --

\section{-- Insert Figure 2 around here --}

\subsection{Implementation of product and process innovation}

Group A has a wide range of brands incorporating many fashion and style elements, because its products are closely related to personal use. Product innovation practices are implemented radically in the $\Delta$ and $\Psi$ product families and incrementally in the $\Phi$ product family. A high level of radical innovation implies a shorter product lifecycle for the $\Delta$ and $\Psi$ families, in addition to 
higher customer expectations of frequent product variation. Group A's innovation practices are categorised as the introduction of new products (i.e. radical innovation), the restyling of existing products (i.e. incremental innovation such as changing colours or textile materials) and continuous improvement (i.e. process innovation). Product innovation is also restricted by the production process capabilities; for example, changing the design of some products is more challenging because of the need to change the machinery or moulds. Therefore, the functional products (the $\Phi$ product family) are restyled every two years, while for the products with more flexible production processes and fashion elements (the $\Delta$ and $\Psi$ product families), customers expect new styles every 9-12 months. Innovation generation in group A is a collective process involving various departments. It starts with ideation, presented through the group's internal software platform; the concerned departments (i.e. design, R\&D, production and supply chain) then vote on the idea based on a feasibility study, after which the finance department has to approve the product launch. Group A offers a product portfolio of 16,500 stock-keeping units every year.

In the case of group B, product innovation is mainly performed incrementally. The product innovation practices focus on changing a few technical specifications, using new/improved materials to achieve better performance or add strength to the engineered tools. This is in addition to the introduction of product variety or the versatility of geometric dimensions of the tools. This slow innovation may be due to the characteristics of the group's products. Product innovation is carried out collaboratively by the R\&D and production departments. The supply chain manager is involved at the purchasing and production planning stages-i.e. in the implementation phase. 
Due to the high-tech nature of group B's products, radical innovation does not frequently occur. Radical innovation is mainly related to the characteristics of the materials used in producing group B's tools - for example, introducing completely new material composition for the tools. Hence, supplier criticality is observed if group B decides to use certain rare materials that are hard to procure or pre-process. However, group B can perform selective radical innovation based on customers' special requests for manufacturing tools with new and improved characteristics.

In both corporate groups, process innovation is performed to improve performance. The main innovation practices implemented are therefore continuous improvement projects in production units. These projects address cost reductions, cost efficiency, maximisation of machinery utilisation, lowering of labour costs, training of personnel to work on different machinery, production line reconfiguration and inventory reduction, in addition to processing development projects. In group A, production process innovation depends on feasibility studies of the costs of the innovation processes, while in group B, due to technological restrictions, process innovation mainly occurs in the management of production functions rather than in the production process itself. Usually, a team is formed from different functional areas to implement the improvement project and follow up on its progress. The product and process typologies, along with the innovation practices, are summarised in Table 5.

\section{-- Insert Table 5 around here -}

\section{Discussion}


This section reports the impact of innovation implementation (process and product) on supply and distribution network design in section 5.1, on operations in section 5.2 , on collaboration and coordination in section 5.3, and on supply chain strategy in section 5.4. The paper's theoretical contribution and the managerial implications are synthesised in section 5.5.

\subsection{Supply and distribution network design}

Supply and distribution network settings and decisions (i.e. location and selection of supplier/distributor) are bounded by contractual strategic agreements. Businesses try not to sabotage their relationships with long-term suppliers as they seek to enhance their collaboration. There is little evidence to suggest that innovation practices' implementation affects supply and distribution network design, or redesign, as illustrated by a group A response: "No we don't involve the distributors - it's only an internal analysis”. Moreover, there is little evidence that innovation practices' implementation affects facility localisation/globalisation decisions.

\subsection{Operations}

Process innovation (e.g. continuous improvement projects) implementation is concentrated in the production and human resources management areas. Improvement projects are implemented to maximise equipment utilisation, improve production line efficiencies, establish good practices in the inventory management area, decrease inventory investment and benchmark best production practices. Additionally, to optimise space utilisation (for example, in warehousing), the number of SKUs can be decreased (or clustered). As indicated by a group A respondent, "For sure, process innovation has a strong impact on the supply chain in terms of service, production capacity [and] complexity". Other continuous improvement projects 
address logistics and warehousing centralisation, in addition to shifting to third-party logistics and transportation and economically optimising ordering quantities.

In the human resources area, projects concern enhancing personnel skills, training labour to work equally effectively on different production lines, and optimising man-hour utilisation. One group B respondent said: “[we] maintain a team of people always available to produce different products, to keep the number of workers as stable as possible”.

The case findings suggest that process innovation practices are usually implemented to achieve greater cost efficiencies and to improve operational performance, as illustrated by this group A response: "the company achieves cost reduction by revising all the processes, reengineering all the processes, including the supply chain". Furthermore, in the innovation generation phase for new products, supply chain executives intervene to highlight operational performance parameters that might be affected by new products - for instance, lead time and economic ordering quantity.

\subsection{Collaboration and coordination}

\subsubsection{Internal coordination}

Internal coordination proved to be a vital factor in new product development, as indicated by a group B respondent: “For most of the products, then, it's more that we have projects with production areas, the production team participates, in addition to the other stakeholders who must be part of those projects to make them deliverable". However, the decision to initiate new product development is the responsibility of the $R \& D$ department, so there is minimum collaboration in the introduction phase. This was affirmed by a group B respondent: "The supply chain as an organisation is little involved [in new product development]. Our task is not at the beginning of product development, but more in the R\&D and the production technology". 
Likewise, a group A interviewee said: "If we are speaking of a new product platform, in that case usually I have no major remarks in the idea generation phase, but I will start to write my recommendations only when the project really starts". The supply chain department thus starts its involvement and coordination when the physical product is planned for production.

\subsubsection{Supplier and distributor collaboration}

Supplier collaboration is more prevalent when implementing product innovation practices (e.g. new product development) than process innovation practices (e.g. continuous improvement projects). Suppliers are involved in the R\&D departments in group B: "we have developed programmes of involvement between $R \& D$ and the suppliers". The extent of supplier collaboration and involvement depends on the contractual relationship with the focal company; it also depends on the nature of the product and the technical capacity of the supplier, as indicated by this response: "[collaboration] depends on the supplier and what the product is ... if we are developing things jointly in $R \& D$, then there has to be a contract".

It is apparent that supplier collaboration is also moderated by two more factors, innovation typology and product physical characteristics: "Depending on what the products look like ... if they're something completely new or just a modification."

In the distribution function area, group B tries to implement continuous improvement projects in its distribution centres- "we are also looking into implementing this [project] in the distribution centres so as to use the same methodology" - which will lead to more information regarding the continuous improvement projects conducted with their carriers. In product innovation practice implementation, distributor involvement is minimal: distributors and 
carriers are generally involved only if the new product development or product modification will affect the handling of the finished goods. This is the case when changing the physical dimensions or nature of a product, as indicated in this case response: "In special cases, I think we need special handling”.

\subsection{Supply chain strategy}

The case findings suggest that top managers display greater flexibility if they expect the change to benefit the corporate's economic performance. This shapes their decision-making, as illustrated by this group B response: "We defined a strategy of change and we have some ongoing projects and some new projects to start in the future in order to improve the general performance of the supply chain". There is also a growing emphasis on benchmarking best practices, especially those related to process innovation: "[The production department] has already established best practices and they are making improvements in the organisation”.

Reflection on Fisher's (1997) model is necessary in order to understand the dynamics between innovation implementation (especially pertaining to products) and supply chain strategy. In his model, Fisher (1997) proposes that a physically efficient supply chain strategy matches functional products, whilst a market responsive supply chain strategy matches innovative products; otherwise the supply chain will be in mismatch. The four supply chains investigated in groups A and B are shown in Figure 3. This classification is based on product typology, innovation novelty data (summarised earlier in Table 3) and supply chain outline data (summarised earlier in Table 2). Product families B and $\Phi$ are considered functional products 
due to their low variety and the stable demand. Product families $\Delta$ and $\Psi$ are considered innovative products due to their rapid change and many associated new product development activities. The supply chain of group A (for $\Phi, \Delta$ and $\Psi$ ) has an efficiency strategy focusing on cost reductions and efficiency gains, whilst the supply chain of group B (for B) focuses on highquality service, overnight delivery and responsiveness.

This analysis is not in line with Fisher's (1997) classification of supply chain strategy as purely responsive or purely efficient. Obviously, Fisher's (1997) model does not hold in all contexts - for example, in the findings of the present research. Similarly, Fisher's (1997) model was not verified in the work of other scholars (e.g. Selldin and Olhager, 2007; Lo and Power, 2010) who statistically tested its propositions with large empirical data sets.

Notably, the examined supply chains in the present research are not in a state of fit, even though their economic performance is competitive. The ability of corporate groups A and B to sustain such competitive economic performance with supply chains in a state of mismatch and misfit remains an open question and might be a direction for future research.

\section{-- Insert Figure 3 around here -}

\subsection{Synthesis}

This synthesis of the analyses comprises two main sub-sections. The first subsection (5.5.1) discusses the practical and managerial implications of innovation implementation in the supply chain. The second subsection (5.5.2) discusses the implications of considering innovation implementation as a contextual factor and the implications in relation to contingency theory.

\subsubsection{Innovation implementation in the supply chain}


The analysis of the findings suggests that introducing and implementing product and process innovation practices affects intra-organisational functions and supply chain relationships. However, before businesses jump on the innovation bandwagon, a clear understanding should be established of how innovation implementation will influence their processes and performance.

Process and product innovation practices' implementation has a significant impact on operations due to a concentration of continuous improvement projects and new product development activities in the production area. A similar impact can be found on supply chain strategy and decision-making. Moreover, it enables and enhances collaboration and information sharing between supply chain members. However, there is no significant evidence that innovation implementation affects facility localisation or globalisation decisions (i.e. the key elements of supply chain configuration), which are mainly based on quality assurance and costefficiency considerations.

The case findings suggest that for successful process and product innovation practice implementation, businesses first must enhance internal coordination and their cross-functional business team models. At the supply chain level, collaboration and information sharing are key factors for the successful implementation of innovation. Businesses are displaying an awareness of the need for better collaboration, yet no solid plans are being developed to enhance supply chain collaboration. Table 6 summarises product and process innovation implementation in various supply chain configuration settings.

\section{-- Insert Table 6 around here --}


The paper's findings coincide with the earlier argument (e.g. Chi et al., 2009; Skipworth et al., 2015) that supplier selection, internal coordination, and collaboration and information sharing practices should be aligned in order to achieve higher performance and greater competitiveness.

Supply chain members need to foresee the added value of such collaboration and how it will improve their performance before they begin collaborating in innovation projects. Therefore, to maximise the tangible impact of innovation implementation, the business incentives of all the supply chain members should be aligned and the supply chain should be in a state of fit. If the supply chain is in misalignment (misfit), the benefits of implementing innovation will be concentrated intra-organisationally (i.e. in the focal firm) and this might, in the long run, exploit the contributions of upstream and downstream members. Better economic performance and greater responsiveness along the supply chain will therefore be hard to maintain

Dyadic relationships constitute a key area for further improvement, as they challenge supply chain reconfiguration before implementing innovation practices. Strategic agreements play an important role in managing raw material suppliers, greatly strengthening the dyadic relationships. Another important factor influencing dyadic relationships is supplier criticality, which stems from the core technological competence of some suppliers. For instance, the findings of the present research indicate that innovation implementation has a negligible impact on decisions regarding supplier selection, supply network design, distributor and carrier selection, and transportation mode. Apparently, these decisions are bounded mainly by supplier technical capacity, contractual agreements, long-term strategic goals shared with suppliers and distributor capacities. 


\subsubsection{Innovation implementation as a contextual factor}

The analyses suggest that supply chain collaboration is employed as a key strategy for mitigating the shortcomings of supply chain misfit. According to contingency theory concepts, the implementation of innovation practices should have caused the corporate groups to alter their supply chain configurations. As their environment is changing, so should their structure and strategy. However, it was infeasible for the groups to do so, given the constraints related to efficiency gains or supplier criticality. Instead, they employed collaborative strategies to exploit the resources of their supply chain members and overcome the strategy-structure-environment misfit.

The analyses suggest that further efforts are needed to customise supply chain configurations to match the particulars of their contextual environments. Although the two corporate groups differ in their contextual factors, such as industry sector, size (i.e. number of employees), supply chain footprint (i.e. location) and products (characteristics, maturity and targeted market), the main motivation driving their decision-making is efficiency gains. Moreover, they displayed similarity in their supply chain configuration decisions, which are motivated mainly by cost-savings, and in fostering long-term relationships with their suppliers.

The analyses support the contingency theory concept that the context-sensitivity of supply chains influences performance. In this regard, it is important to emphasise the significance of the type of innovation, as different innovation practices affect the supply chain in different ways.

On the theoretical advancement side, this paper proposes that research would benefit from further investigating the magnitude of the contextual factors, not only their nature. For instance, in the findings of group A, product innovations are frequently introduced, resulting in the 
challenge of managing high uncertainty of product demand. The effect of this product innovation implementation (i.e. new product development) propagates along the supply chain to create challenges in inventory management due to frequent product obsolescence. The effect of contextual factors is therefore significant, not only because of their nature, but also due to their frequency of occurrence and the magnitude and range of their effects on supply chains at large.

\section{Conclusion}

The importance of this study stems from the scarcity of interdisciplinary research. Despite the theoretical and practical need for relevant interdisciplinary studies, supply chain and innovation management remain two important streams of research with little communication. Recent studies (e.g. Lo and Power, 2010; Pero et al., 2010) offer beneficial insights into the alignment between innovation introduction and supply chain design. Yet, to the authors' knowledge, this paper is one of the earliest attempts — along with Arlbjørn et al. (2011) — to incorporate the dimensions of both product and process innovation. The majority of the available scholarly publications focuses on new product development and its impact on a few of the supply chain functions, while overlooking the process innovation dimension. Furthermore, the present research contributes in investigating the supply chain from a holistic perspective instead of the functional perspective currently followed.

The provided analyses help innovation researchers and managers in better understanding of the actual tangible impact of innovation implementation throughout the supply chain. One can conclude that successful implementation of innovation practices that ensures streamlined value creation along the entire supply chain should be characterised by: (1) a change in the mind-set and developing a clear innovation strategy that should be communicated beforehand to all the 
supply chain members; (2) seeing transformation as a long-term process and transformative innovation as cyclical, taking place after a number of trials and (3) having a cross-functional and inter-organisational nature. The research results offer beneficial insights to supply chain and innovation practitioners for their decision-making when implementing innovation; it guides them to leverage on collaboration to overcome the potential shortcomings of supply chain misfit. This will help improve the innovation management and will help achieve and sustain an improved supply chain performance.

The authors acknowledge the potential limitations of this research. Firstly, disentangling the various contextual factors is not easy, mainly due to their interrelated effects. The authors therefore focused their effort in the data analysis phase on conducting multiple coding rounds to ensure high quality analysis. Secondly, considering that case-based research does not allow for statistical generalisability, the two corporate groups and the examined product families should not be regarded as representative of their countries or industrial sectors. Rather, the cases represent opportunities to establish analytical generalisability and to develop a learning platform to advance our knowledge on the studied phenomena. The authors have striven to ensure case study validity and data analysis reliability, as demonstrated earlier in the methodology section. Although "[bias] is a fundamental human characteristic", not limited to certain methodology (Flyvbjerg, 2006, p.234), the authors argue that the present data and findings are of a quality satisfactory for scientific research.

In the future, research would benefit from rigorously synthesising the configuration settings with respect to additional contextual factors pertaining to organisational structures or to industry sector particularities. Furthermore, the findings of this research reveal that collaboration is prioritised and employed as a strategy for performance improvement in the 
analysed corporate groups. There is higher reliance on European suppliers in preference to the traditional supply strategies of outsourcing and choosing low-cost countries. Therefore, collaborative agreements and partnerships among supply chain members emerge as an interesting topic for future research.

\section{References}

1. Abernathy, W., and Clark, K., (1985), "Innovation mapping, the winds of creative destruction", Research Policy, Vol. 14 No. 1, pp. 3-22.

2. Adams, R., (2003), "Perceptions of innovations: exploring and developing innovation classification". PhD thesis, Cranfield University Press, Cranfield, UK.

3. Aitken, J., Childerhouse, P., Christopher, M. and Towill, D. 2005. "Designing and managing multiple pipelines.” Journal of Business Logistics, Vol. 26, No. 2, pp. 73-96.

4. Amin, S.H., and Zhang, G., (2012), "An integrated model for closed-loop supply chain configuration and supplier selection: multi-objective approach", Expert Systems with Applications, Vol. 39 No. 8, pp. 6782-6791.

5. Amini, M., and Li, H., (2011), "Supply chain configuration for diffusion of new products: an integrated optimization approach", Omega, Vol. 39 No. 3, pp. 313-322.

6. Arlbjørn, J.S., de Haas, H., and Munksgaard, K.B., (2011), "Exploring supply chain innovation", Logistics Research, Vol. 3 No. 1, pp. 3-18.

7. Arlbjørn, J., and Paulraj, A., (2013), "Special topic forum on innovation in business networks from a supply chain perspective: current status and opportunities for future research", Journal of Supply Chain Management, October, pp. 3-11. 
8. Baxter, P., and Jack, S., (2008), "Qualitative case study methodology: study design and implementation for novice researchers", The Qualitative Report Volume, Vol. 13 No. 4, pp. $544-559$.

9. Bellamy, M.A., Ghosh, S., and Hora, M., (2014), "The influence of supply network structure on firm innovation", Journal of Operations Management, Vol. 32, No. 6, pp. $357-373$.

10. Blackhurst, J., Wu, T., and O’Grady, P., (2005), "PCDM: a decision support modeling methodology for supply chain, product and process design decisions", Journal of Operations Management, Vol. 23 No.3, pp. 325-343.

11. Blaug, M., (1963), "A survey of the theory of process innovations", Economica, Vol. 30 No. 117, pp. 13-32.

12. Brandon-Jones, E., Squire, B., Autry, C.W., and Petersen, K.J., (2014), “A contingent resource-based perspective of supply chain resilience and robustness", Journal of Supply Chain Management, Vol. 50 No. 3, pp. 55-73.

13. Burgess, T.F., and Gules, H.K., (1998), "Buyer-supplier relationships in firms adopting advanced manufacturing technology: an empirical analysis of the implementation of hard and soft technologies", Journal of Engineering and Technology Management, Vol. 15 Nos. 2-3, pp. 127-152.

14. Cagliano, R., Caniato, F., Golini, R., Kalchschmidt, M., and Spina, G., (2008), "Supply chain configurations in a global environment: a longitudinal perspective", Operations Management Research, Vol. 1 No. 2, pp. 86-94.

15. Caniato, F., Golini, R., and Kalchschmidt, M., (2013), "The effect of global supply chain configuration on the relationship between supply chain improvement programs and 
performance”, International Journal of Production Economics, Vol. 143 No. 2, pp. 285293.

16. Chandra, C., and Grabis, J., (2007), Supply Chain Configuration-Concepts, Solutions, and Applications. Springer, New York.

17. Chi, T., Kilduff, P.P.D., and Gargeya, V.B., (2009), "Alignment between business environment characteristics, competitive priorities, supply chain structures, and firm business performance", International Journal of Productivity and Performance Management, Vol. 58 No. 7, pp. 645-669.

18. Choi, J., Hyun, A.S., and Cha, M.S., (2013), "The effects of network characteristics on performance of innovation clusters", Expert Systems with Applications, Vol. 40 No. 11, pp. $4511-4518$.

19. Chopra, S., and Meindl, P., (2007), Supply Chain Management: Strategy, Planning, and Operation. 3rd ed., Pearson Prentice Hall, Upper Saddle River, New Jersey.

20. Christensen, C.M., (1997), The Innovator's Dilemma: When New Technologies Cause Great Firms to Fail. Harvard Business School Press, Boston, Massachusetts.

21. Crippa, R., Larghi, L., Pero, M., and Sianesi, A., (2010), “The impact of new product introduction on supply chain ability to match supply and demand", International Journal of Engineering Science and Technology, Vol. 2 No. 9, pp. 83-93.

22. Damanpour, F., and Gopalakrishnan, S., (1998), "Theories of organizational structure and innovation adoption: the role of environmental change", Journal of Engineering and Technology Management, Vol. 15, No.1, pp. 1-24.

23. Drazin, R., and Van de Ven, A.H., (1985), “Alternative forms of fit in contingency theory”, Administrative Science Quarterly, Vol. 30, No. 4 (Dec., 1985), pp. 514-539. 
24. Drucker, P., (1985), “The discipline of innovation”, Harvard Business Review, Vol. 3 No. 63, p. 67.

25. Ebben, J.J., and Johnson, A.C., (2005), "Efficiency, flexibility, or both? Evidence linking strategy to performance in small firms", Strategic Management Journal, Vol. 26 (October 2003), pp. 1249-1259.

26. Ellram, L.M., and Cooper, M.C., (2014), "Supply chain management: it's all about the journey, not the destination", Journal of Supply Chain Management, Vol. 50, pp. 8-20.

27. Farahani, R.Z., Shabnam, R., Drezner, T., and Fallah, S., (2014), "Competitive supply chain network design: an overview of classifications, models, solution techniques and applications", Omega, Vol. 45 (June 2014), pp. 92-118.

28. Fine, C.H., (1998), Clockspeed: Winning Industry Control in the Age of Temporary Advantage, Perseus Books, Reading, Massachusetts.

29. Fine, C.H., (2000), “Clockspeed-based strategies for supply chain design”, Production and Operations Management, Vol. 9 No. 3, pp. 213-221.

30. Fisher, M.L., (1997), "What is the right supply chain for your product?” Harvard Business Review, Vol. 75, No. 2, pp. 105-116.

31. Fiss, P.C., Cambré, B., and Marx, A. (eds.), (2013), "Configurational theory and methods in organizational research", Research in the Sociology of Organizations, Volume 38, Emerald, Bingley, UK.

32. Fixson, S.K., (2005), "Product architecture assessment: a tool to link product, process, and supply chain design decisions", Journal of Operations Management, Vol. 23 Nos. 3/4, pp. $345-369$. 
33. Flynn, B.B., Huo, B., and Zhao, X., (2010), "The impact of supply chain integration on performance: a contingency and configuration approach", Journal of Operations Management, Vol. 28 No. 1, pp. 58-71.

34. Flyvbjerg, B., (2006), "Five misunderstandings about case-study research", Qualitative Inquiry, Vol. 12 No. 2, pp. 219-245.

35. Flyvbjerg, B., (2011), "Case study”, in Norman K. Denzin and Yvonna S. Lincoln (eds.), The Sage Handbook of Qualitative Research. 4th ed., Chapter 17, pp. 301-316, Sage, Thousand Oaks, California.

36. Fry, L.W., and Smith, D.A., (1987), "Congruence, contingency, and theory building", Academy of Management Review, Vol. 12 No. 1, pp. 117-132.

37. Fugate, B.S., Mentzer, J.T., and Stank, T.P., (2010), "Logistics performance: efficiency, effectiveness and differentiation”, Journal of Business Logistics, Vol. 31 No. 1, pp. 43-62.

38. Gan, T.S., and Grunow, M., (2013), "Concurrent product-supply chain design: a conceptual framework and literature review", Procedia CIRP, Vol. 7, pp. 91-96.

39. Garcia, R., and Calantone, R., (2002), “A critical look at technological innovation typology and innovativeness terminology: a literature review", Journal of Product Innovation Management, Vol. 19 No. 2, pp.110-132.

40. GCI and Capgemini, (2016), Future Supply Chain 2016, Capgemini website accessed April 2016 and May 2018.

41. Gibbert, M., and Ruigrok, W., (2010), “The 'what' and 'how' of case study rigor: three strategies based on published research", Organisational Research Methods, Vol. 13 No. 4, pp. $710-737$. 
42. Gimenez, C., van der Vaart, T., and Pieter van Donk, D., (2012), "Supply chain integration and performance: the moderating effect of supply complexity", International Journal of Operations and Production Management, Vol. 32 No. 5, pp. 583-610.

43. Goldsby, T.J., and Zinn, W., (2016), “Technology innovation and new business models: can logistics and supply chain research accelerate the evolution?" Journal of Business Logistics, Vol. 37, No. 2, pp. 80-81.

44. Gopalakrishnan, S., and Damanpour, F., (1997), "A review of innovation research in economics, sociology and technology management", International Journal of Management Science, Vol. 25 No. 1, pp. 15-28.

45. Harland, C., (1996), "Supply chain management: relationships, chains and networks", British Journal of Management, Vol. 7 (Special Issue, March), pp. S63-S80.

46. Harland, C., Zheng, J., Johnsen, T., and Lamming, R., (2004), “A conceptual model for researching the creation and operation of supply networks", British Journal of Management, Vol. 15 No. 1, pp. 1-21.

47. Holahan, P.J., Sullivan, Z.Z., and Markham, S.K., (2014), "Product development as core competence: how formal product development practices differ for radical, more innovative, and incremental product innovations", Journal of Product Innovation Management, Vol. 31 No. 2, pp. 329-345.

48. Jayaram, J., Ahire, S.L., and Dreyfus, P., (2010), “Contingency relationships of firm size, TQM duration, unionization, and industry context on TQM implementation-a focus on total effects”, Journal of Operations Management, Vol. 28 No. 4, pp. 345-356. 
49. Kearney, A.T., and WHU, (2015), "Digital Supply Chains: Increasingly Critical for Competitive Edge.” European A.T. Kearney/WHU logistics study. A.T. Kearney website accessed May 2016.

50. Ketokivi, M., and Choi, T., (2014), "Renaissance of case research as a scientific method", Journal of Operations Management, Vol. 32 No. 5, pp. 232-240.

51. Langley, C.J., and Holcomb, M.C., (1992), "Creating logistics customer value”, Journal of Business Logistics, Vol. 13 No. 2, pp. 1-27.

52. Lau, A.K., (2014), "Influence of contingent factors on the perceived level of supplier integration: a contingency perspective", Journal of Engineering and Technology Management, Vol. 33, pp. 210-242.

53. Lee, H.L., (2002), "Aligning supply chain strategies with product uncertainties", California Management Review, Vol. 44 No. 3, pp. 10-119.

54. Lee, H.L., (2004), “The triple-A supply chain”, Harvard Business Review, Vol. 82, No. 10, pp. 102-112.

55. Lo, S.M., and Power, D., (2010), “An empirical investigation of the relationship between product nature and supply chain strategy", Supply Chain Management: An International Journal, Vol. 15 No. 2, pp. 139-153.

56. MacCarthy, B.L., Blome, C., Olhager, J., Srai, J.S., and Zhao, X., (2016), “Supply chain evolution-theory, concepts and science", International Journal of Operations and Production Management, Vol. 36 No. 12, pp. 1696-1718.

57. Manuj, I., and Mentzer, J.T., (2008), “Global supply chain risk management”, Journal of Business Logistics, Vol. 29 No. 1, pp. 133-155. 
58. Marsillac, E., and Roh, J.J., (2014), “Connecting product design, process and supply chain decisions to strengthen global supply chain capabilities", International Journal of Production Economics, Volume 147, Part B, January 2014, pp. 317-329.

59. Melnyk, S.A., Narasimhan, R., and DeCampos, H.A., (2014), "Supply chain design: issues, challenges, frameworks and solutions", International Journal of Production Research, Vol. 52 No. 7, pp.1887-1896.

60. Melo, M.T., Nickel, S., and Saldanha-da-Gama, F., (2009), "Facility location and supply chain management-a review”, European Journal of Operational Research, Vol. 196 No. 2, pp. 401-412.

61. Mentzer, J.T., DeWitt, W., Keebler, J.S., Min, S., Nix, N.W., Smith, C.D., and Zacharia, Z.G., (2002), "Defining supply chain management”, Journal of Business Logistics, Vol. 22 No. 2, pp. 1-25.

62. Miles, M.B., and Huberman, A.M., (1994). Qualitative Data Analysis: An Expanded Sourcebook. $2^{\text {nd }}$ ed., Sage, Thousand Oaks, California.

63. Miller, D., (1996), “Configurations revisited,” Strategic Management Journal, Vol. 17, pp. $505-512$.

64. Mintezberg, H. (1979), The Structuring of Organisations. New Jersey, Prentice-Hall.

65. Oliver, R.K., and Weber, M.D., (1982), Supply-chain management: logistics catches up with strategy. In M.L. Christopher (ed.), Logistics: The Strategic Issues (pp. 63-75). Chapman \& Hall, London, UK.

66. Pashaei, S., and Olhager, J., (2015), "Product architecture and supply chain design: a systematic review and research agenda", Supply Chain Management: An International Journal, Vol. 20 No. 1, pp. 98-112. 
67. Patton, M., (1990), Qualitative Evaluation and Research Methods. Sage, Beverly Hills, California.

68. Pero, M., Abdelkafi, N., Sianesi, A., and Blecker, T., (2010), "A framework for the alignment of new product development and supply chains", Supply Chain Management: An International Journal, Vol. 15 No. 2, pp. 115-128.

69. Persson, F., and Olhager, J., (2002), "Performance simulation of supply chain designs", International Journal of Production Economics, Vol. 77, No. 3, pp. 231-245.

70. Rogers, M., (1998), “The definition and measurement of innovation”, Melbourne Institute Working Paper, No. 10/98.

71. Rowley, J., (2002), “Using case studies in research”, Management Research News, Vol. 25 No. 1, pp. 16-27.

72. Saldaňa, J., (2012), The Coding Manual for Qualitative Researchers. 2nd ed., Sage. Thousand Oaks, California.

73. Schumpeter, J.A., (1939), Business Cycles. McGraw-Hill, New York.

74. Selldin, E. and Olhager, J. (2007) 'Linking products with supply chains: Testing Fisher's model', Supply Chain Management: An International Journal, Vol. 12, No. 1, pp.42-51.

75. Skipworth, H., Godsell, J., Wong, C.Y., Saghiri, S., and Julien, D., (2015), “Supply chain alignment for improved business performance: an empirical study", Supply Chain Management: An International Journal, Vol. 20 No. 5, pp. 511-533.

76. Sousa, R., and Voss, C.A., (2008), “Contingency research in operations management practices", Journal of Operations Management, Vol. 26 No. 6, pp. 697-713.

77. Stavrulaki, E., and Davis, M., (2010), “Aligning products with supply chain processes and strategy”, International Journal of Logistics Management, Vol. 21 No. 1, pp. 127-151. 
78. Tan, K.C., Kannan, V.R., Handfield, R.B., and Ghosh, S., (1999), "Supply chain management: an empirical study of its impact on performance", International Journal of Operations and Production Management, Vol. 19 No. 10, pp. 1034-1052.

79. Tsinopoulos, C., and Mena, C., (2015), "Supply chain integration configurations: process structure and product newness", International Journal of Operations and Production Management, Vol. 35 No. 10, pp. 1437-1459.

80. Ülkü, S., and Schmidt, G.M., (2011), "Matching product architecture and supply chain configuration", Production and Operations Management, Vol. 20 No. 1, pp. 16-31.

81. Van der Vaart, T., Pieter van Donk, D., Gimenez, C., and Sierra, V., (2012), "Modelling the integration-performance relationship: collaborative practices, enablers and contextual factors", International Journal of Operations and Production Management, Vol. 32 No. 9, pp. 1043-1074.

82. van Hoek, R., and Chapman, P., (2007), "How to move supply chain beyond cleaning up after new product development." Supply Chain Management: An International Journal, Vol. 12, No. 4, pp. 239-244.

83. Venkatraman, N., (1989), "The concept of fit in strategy research: toward verbal and statistical correspondence”, Academy of Management Review, Vol. 14 No. 3, pp. 423-444.

84. Voss, C., Tsikriktsis, N. and Frohlich, M., (2002) "Case research in operations management.” International Journal of Operations \& Production Management, Vol. 22, No. 2, pp.195-219.

85. Yin, R.K., (2014), Case Study Research: Design and Methods. 5th ed., Sage Publications Inc., Thousand Oaks, California. 
86. Zhang, D., Linderman, K., and Schroeder, R.G., (2012), "The moderating role of contextual factors on quality management practices", Journal of Operations Management, Vol. 30 No. 1, pp. 12-23.

87. Zhu, Q., Sarkis, J., and Lai, K.H., (2012), "Green supply chain management innovation diffusion and its relationship to organizational improvement: an ecological modernization perspective", Journal of Engineering and Technology Management, Vol. 29 No. 1, pp. $168-185$.

88. Zimmermann, R., Miguel, D.F.L., and Moreira, A.C., (2016), "The influence of supply chain on the innovation process: a systematic literature review", Supply Chain Management: An International Journal, Vol. 21, No. 3, pp. 289-304. 
Table 1 . The innovation practices, context, scope and novelty addressed in the literature.

\begin{tabular}{|c|c|c|c|c|c|}
\hline \multirow[t]{2}{*}{ Innovation Practices } & \multicolumn{2}{|c|}{ Context } & \multirow[t]{2}{*}{ Scope } & \multirow[t]{2}{*}{ Innovation Novelty } & \multirow[t]{2}{*}{ Source } \\
\hline & Prd & Prc & & & \\
\hline $\begin{array}{ll}- & \text { Developing new products } \\
- & \text { New forms of organisational structure } \\
- & \text { Opening up new markets } \\
- & \text { New production functions } \\
- & \text { Finding new sources of raw material supply }\end{array}$ & $\checkmark$ & $\checkmark$ & $\begin{array}{l}\text { To advance industrial } \\
\text { competitiveness }\end{array}$ & $\begin{array}{ll}\checkmark & \text { Radical } \\
\checkmark & \text { Incremental } \\
\checkmark & \text { Competence enhancing }\end{array}$ & Schumpeter (1939) \\
\hline $\begin{array}{ll}- & \text { Using new resources } \\
- & \text { Developing existing knowledge resources }\end{array}$ & $\checkmark$ & $\checkmark$ & To create national wealth & $\begin{array}{ll}\checkmark & \text { Radical } \\
\checkmark & \text { Incremental }\end{array}$ & Drucker (1985) \\
\hline $\begin{array}{ll}\text { - } & \text { Investment in machinery, marketing and training } \\
\text { expenditures, } \\
\text { - Developing firms' intellectual property } \\
\text { - } \quad \text { Technology that leads to new or improved } \\
\text { product or process }\end{array}$ & $\checkmark$ & $\checkmark$ & To enhance firm's performance & & Rogers (1998) \\
\hline - Innovative processes that ignites growth & $\checkmark$ & $\checkmark$ & Creating new markets & $\begin{array}{ll}\checkmark & \text { Disruptive } \\
\checkmark & \text { Revolutionary } \\
\checkmark & \text { Evolutionary }\end{array}$ & Christensen (1997) \\
\hline - Introducing new products to the market & $\checkmark$ & $\checkmark$ & $\begin{array}{l}\text { Industrial development and } \\
\text { productivity growth }\end{array}$ & $\begin{array}{ll}\checkmark & \text { Architectural } \\
\checkmark & \text { Niche } \\
\checkmark & \text { Regular } \\
\checkmark & \text { Revolutionary }\end{array}$ & Abernathy and Clark (1985) \\
\hline - New idea, process, product & $\checkmark$ & $\checkmark$ & $\begin{array}{l}\text { Nurturing national economy } \\
\text { Enhancing firm performance }\end{array}$ & $\begin{array}{ll}\checkmark & \text { Radical } \\
\checkmark & \text { Incremental } \\
\checkmark & \text { Technical } \\
\checkmark & \text { Administrative }\end{array}$ & $\begin{array}{l}\text { Gopalakrishnan and } \\
\text { Damanpour (1997) }\end{array}$ \\
\hline
\end{tabular}


Table 2. Innovation practices addressed in the reviewed supply chain literature.

\begin{tabular}{|c|c|c|c|c|c|c|c|c|c|c|}
\hline \multicolumn{2}{|c|}{$\begin{array}{l}\text { Innovation } \\
\text { Novelty }\end{array}$} & \multicolumn{6}{|c|}{$\begin{array}{c}\text { Investigated Innovation Practices in } \\
\text { SC Literature }\end{array}$} & \multirow[t]{2}{*}{$\begin{array}{c}\text { Relation with Supply Chain } \\
\text { Aspect }\end{array}$} & \multirow[t]{2}{*}{$\begin{array}{l}\text { Directions for Future } \\
\text { Research }\end{array}$} & \multirow[t]{2}{*}{ Sources } \\
\hline RL & IL & NPD & NPL & PD & PR & CI & NPI & & & \\
\hline$\bullet$ & • & $\checkmark$ & & $\checkmark$ & & $\checkmark$ & $\checkmark$ & $\begin{array}{l}\text { Production operations, } \\
\text { inventory and warehousing }\end{array}$ & $\begin{array}{l}\text { Optimisation of the } \\
\text { design of supply chains }\end{array}$ & $\begin{array}{l}\text { Blackhurst et al. } \\
(2005)\end{array}$ \\
\hline$\bullet$ & & $\checkmark$ & $\checkmark$ & $\checkmark$ & $\checkmark$ & & & $\begin{array}{l}\text { - Investigating misalignment } \\
\text { between product features and } \\
\text { supply chains } \\
\text { - Investigating the } \\
\text { relationship between product } \\
\text { feature and supply chain } \\
\text { complexity (of configuration, } \\
\text { collaboration and } \\
\text { coordination) }\end{array}$ & $\begin{array}{l}\text { - Developing a } \\
\text { methodology to support } \\
\text { NPD alignment with } \\
\text { supply chain management }\end{array}$ & $\begin{array}{l}\text { Crippa et al. (2010) } \\
\text { Pero et al. (2010) }\end{array}$ \\
\hline & $\bullet$ & & & $\checkmark$ & & $\checkmark$ & $\checkmark$ & $\begin{array}{l}\text { - The impact of product } \\
\text { design on process and supply } \\
\text { chain activities } \\
\text { - Three dimensional } \\
\text { concurrent engineering } \\
\text { (3DCE) }\end{array}$ & $\begin{array}{l}\text { Further explore the } \\
\text { synchronised product- } \\
\text { process-supply chain } \\
\text { design of supply chains } \\
\text { relationships }\end{array}$ & $\begin{array}{l}\text { Fine }(1998,2000) \\
\text { Fixson }(2005) \\
\text { Stavrulaki and Davis } \\
(2010) \\
\text { Marsillac and Roh } \\
(2014)\end{array}$ \\
\hline • & - & $\checkmark$ & $\checkmark$ & $\checkmark$ & $\checkmark$ & & & $\begin{array}{l}\text { - Matching supply chain } \\
\text { structure (make to stock, } \\
\text { assemble to order, build to } \\
\text { order and design to order) } \\
\text { with product innovativeness }\end{array}$ & $\begin{array}{l}\text { Realigning product and } \\
\text { supply chain strategies } \\
\text { Aligning supply chain, } \\
\text { product characteristics } \\
\text { and performance }\end{array}$ & $\begin{array}{l}\text { Fisher (1997), } \\
\text { Selldin and Olhager } \\
\text { (2007), van Hoek } \\
\text { and Chapman } \\
\text { (2007), Stavrulaki } \\
\text { and Davis (2010), } \\
\text { Lo and Power } \\
\text { (2010) }\end{array}$ \\
\hline
\end{tabular}




\begin{tabular}{|c|c|c|c|c|c|c|c|c|c|c|}
\hline & & & & & & & & $\begin{array}{l}\text { - Matching supply chain } \\
\text { strategy to product nature }\end{array}$ & & $\begin{array}{l}\text { Gan and Grunow } \\
\text { (2013), Pashaei and } \\
\text { Olhager (2015) }\end{array}$ \\
\hline & • & $\checkmark$ & $\checkmark$ & $\checkmark$ & $\checkmark$ & $\checkmark$ & $\checkmark$ & $\begin{array}{l}\text { Coordinating retailing } \\
\text { activities with manufacturing } \\
\text { in green innovation } \\
\text { implementation }\end{array}$ & $\begin{array}{l}\text { Investigating pricing and } \\
\text { green innovation } \\
\text { strategies in multi- } \\
\text { channel supply chains }\end{array}$ & Zhang et al. (2012) \\
\hline & $\bullet$ & $\checkmark$ & $\checkmark$ & $\checkmark$ & $\checkmark$ & & & $\begin{array}{l}\checkmark \text { Investigating the relationship } \\
\text { of a firm's supply chain } \\
\text { position (buyer-supplier) and } \\
\text { its innovation output }\end{array}$ & $\begin{array}{l}\text { How to develop a firm's } \\
\text { capacity to absorb } \\
\text { knowledge residing in the } \\
\text { supply network }\end{array}$ & $\begin{array}{l}\text { Bellamy et al. } \\
(2014)\end{array}$ \\
\hline$\bullet$ & $\bullet$ & $\checkmark$ & $\checkmark$ & $\checkmark$ & $\checkmark$ & $\checkmark$ & $\checkmark$ & $\begin{array}{l}\text { Editorial overview of the } \\
\text { impact of innovation on } \\
\text { supply chains }\end{array}$ & $\begin{array}{l}\text { The interplay between } \\
\text { innovation and the } \\
\text { business process; how } \\
\text { firms organise their } \\
\text { structure, their network } \\
\text { and innovation }\end{array}$ & $\begin{array}{l}\text { Arlbjørn and } \\
\text { Paulraj, (2013); } \\
\text { Arlbjørn et al. } \\
\text { (2011) }\end{array}$ \\
\hline
\end{tabular}

Innovation novelty

Investigated

innovation Practices
RL: Radical, IL: Incremental

NPD: New product development, NPL: New product launch, PD: Product design, PR: Product restyling, CI:

Continuous improvement, NPI: New process introduction, P: Intellectual property and patents 
Table 3. Description of the corporate groups A and B.

\begin{tabular}{lll}
\hline & Corporate Group A & Corporate Group B \\
\hline Key informants & Group Head for Supply Chain Planning & Vice President for Supply Chain Management \\
Location & Italy (HQ) - branches in 24 countries & Sweden (HQ) - branches in 14 countries \\
No. of subsidiaries & 6 & 4 \\
Turnover & 1,415 million euros & 3,010 million euros \\
Industry sector & Healthcare products industry & Engineering technology \\
Number of employees & 6,500 & 19,000 \\
Supply network & Local and global & Local and global \\
Distribution network & Local and global & Local and global \\
Production & Local and global & Local and global \\
Assembling & Local and global & N/A \\
Position in SC & Manufacturer/B2B and B2C sales & Manufacturer/B2B sales \\
Product families investigated & 3 (Products $\Phi, \Psi, \Delta)$ & Generic (1) \\
\hline
\end{tabular}


Table 4. Outline of the configuration settings of groups A and B.

\begin{tabular}{|c|c|c|}
\hline & Group A (Products $\Phi, \Psi, \Delta)$ & Group B (Generic Product) \\
\hline $\begin{array}{l}\text { Industry } \\
\text { Sector }\end{array}$ & Health and personal care industry & Engineering technology \\
\hline $\begin{array}{l}\text { Geographical } \\
\text { Location } \\
\text { Dispersion }\end{array}$ & $\begin{array}{l}\text { - Sourcing: global, mainly China } \\
\text { - Production: global, concentrated mainly } \\
\text { in Italy and China } \\
\text { - Sales: global ( } 400 \text { sales points } \\
\text { worldwide) }\end{array}$ & $\begin{array}{l}\text { - Sourcing: global, mainly Europe } \\
\text { - Production: global, concentrated mainly } \\
\text { in Europe } \\
\text { - Sales: global (mostly B2B), huge focus on } \\
\text { online sales }\end{array}$ \\
\hline $\begin{array}{l}\text { Supply } \\
\text { Network } \\
\text { Design }\end{array}$ & $\begin{array}{l}\text { - Global and Italy, for raw materials and } \\
\text { finished products } \\
\text { - Network of suppliers; however, focus on } \\
\text { China suppliers ( } 78 \% \text { of total supply) } \\
\text { - Single supplier for products }(65 \% \text { of } \\
\text { products are supplied by external } \\
\text { vendors) } \\
\text { - Long-term agreements }\end{array}$ & $\begin{array}{l}\text { - Global and Sweden for both raw materials } \\
\text { and finished products } \\
\text { - Fewer suppliers due to need for high- } \\
\text { technology equipment } \\
\text { - Single supplier for products } \\
\text { - Long-term strategic agreements }\end{array}$ \\
\hline $\begin{array}{l}\text { Distribution } \\
\text { Network } \\
\text { Design }\end{array}$ & $\begin{array}{l}\text { - Global sales in } 45 \text { countries to around } \\
40,000 \text { customers worldwide } \\
\text { - Depends on two central warehouses in } \\
\text { Italy and one in Spain; } 11 \text { other } \\
\text { warehouses worldwide } \\
\text { - Locally, few periphery warehouses, and } \\
\text { local distributor warehouses ( } 48 \% \\
\text { distribution in Italy) } \\
\text { - Direct sales outlets to final customer for } \\
\text { only one brand }(35 \% \text { of distribution in }\end{array}$ & $\begin{array}{l}\text { - Global sales in } 100 \text { countries to around } \\
100,000 \text { customers worldwide } \\
\text { - Depends on five distribution centres } \\
\text { located in Europe, Asia and North America } \\
\text { - Locally, few local warehouses } \\
\text { - Direct sales to final customer mainly } \\
\text { through online channels } \\
\text { - Outsourced carriers } \\
\text { - Different transportation modes }\end{array}$ \\
\hline
\end{tabular}


Europe, $12 \%$ in Americas, $4 \%$ in BRIC

countries)

- Outsourced carriers

- Different transportation modes

Collaboration Group A is the strong leading member in Depends heavily on fast delivery

and its supply chain; however, collaboration in distribution and high-tech suppliers, which

Information- supply chain is underdeveloped. Poor requires higher levels of trust, information

Sharing

information visibility both upstream and visibility and synchronisation, and

downstream regarding data on stock or raw knowledge sharing.

materials 
Figure 1. Group A’s products $(\Phi, \Psi, \Delta)$ supply chain footprint.

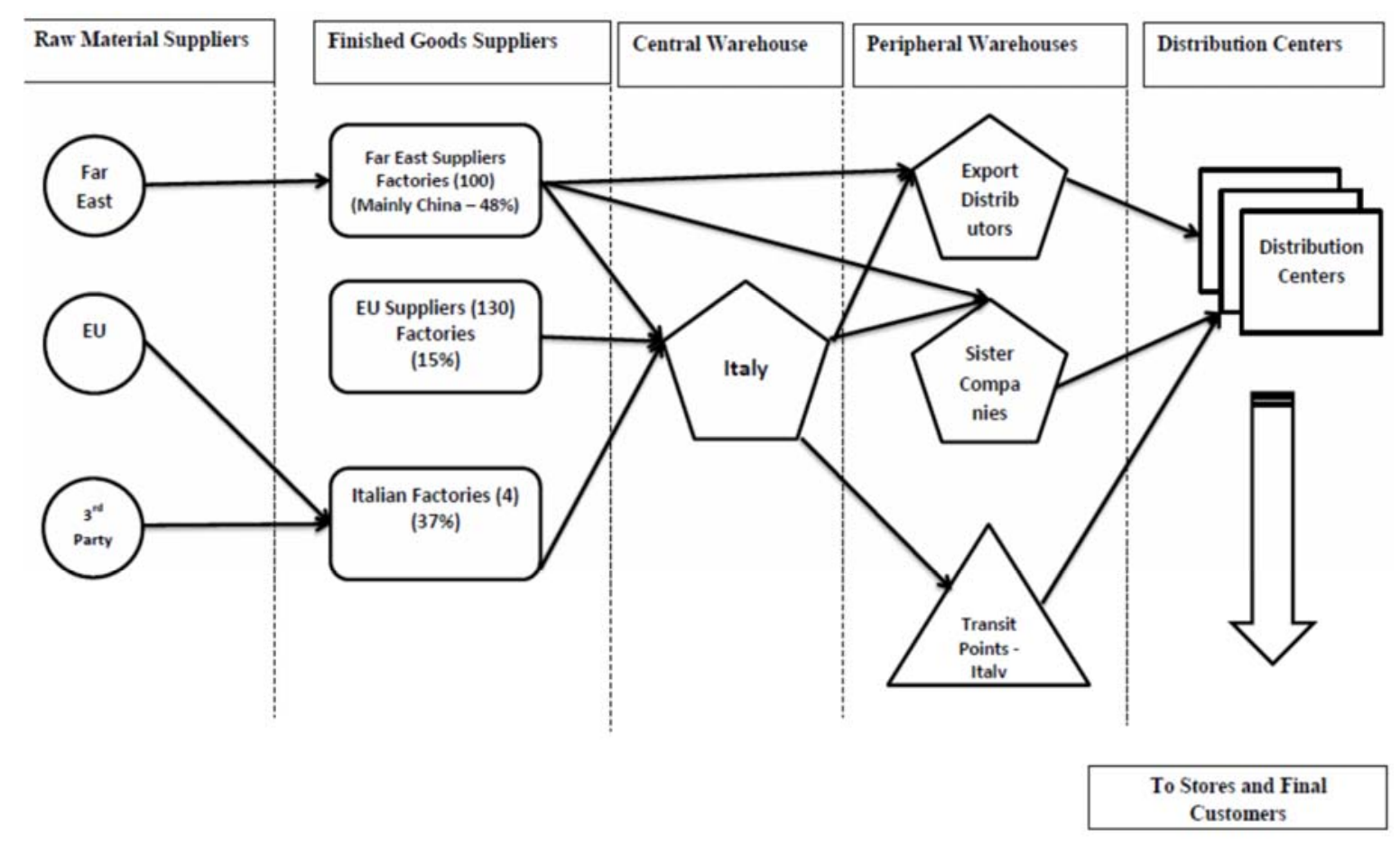


Figure 2. Group B's supply chain footprint.

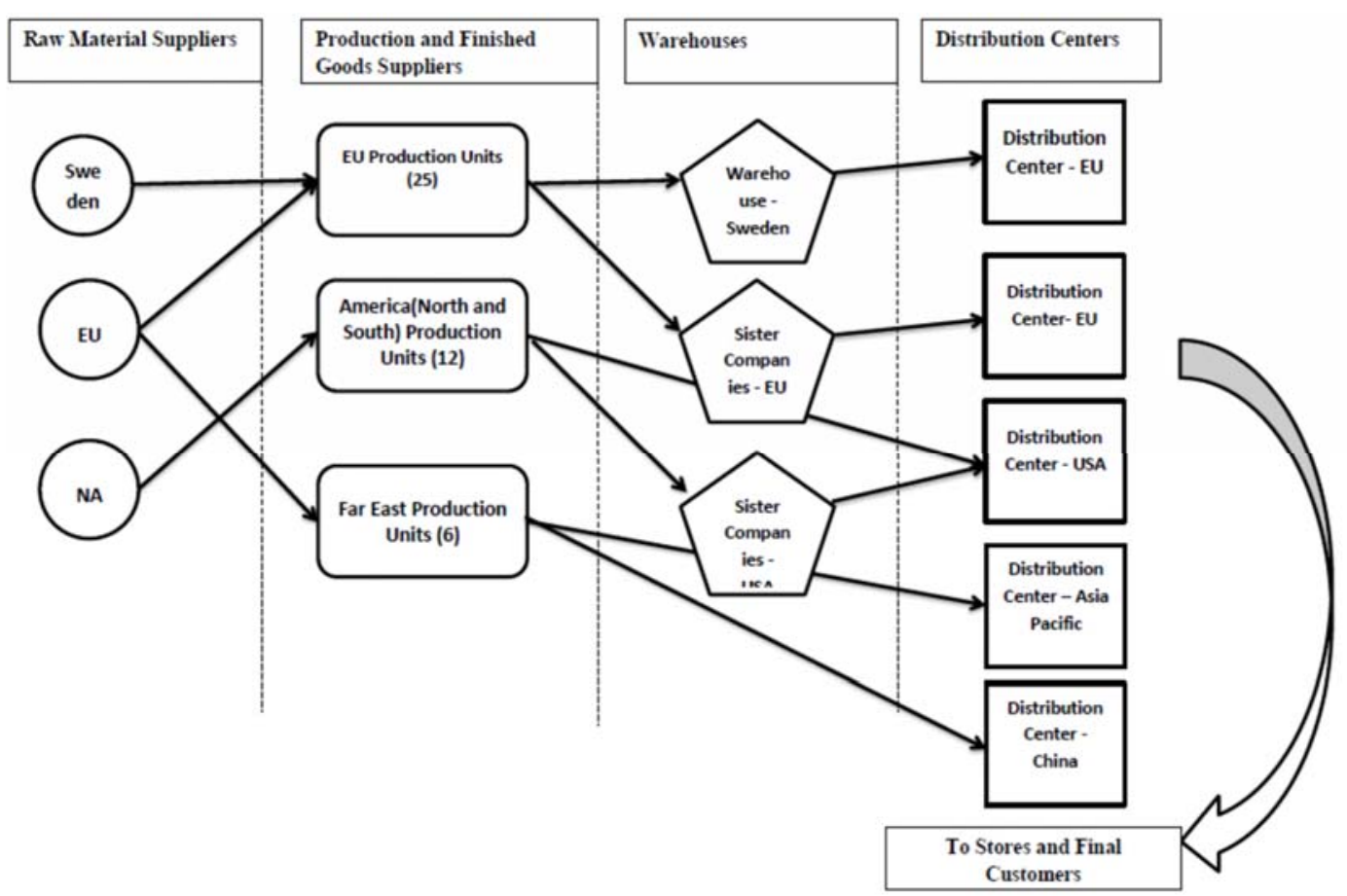


Table 5. Summary of product and process typologies.

\begin{tabular}{|c|c|c|c|c|}
\hline & \multicolumn{3}{|c|}{ Group A } & \multirow[t]{2}{*}{ Group B } \\
\hline & $\begin{array}{l}\text { Product } \\
\text { Family } \Delta\end{array}$ & Product Family $\Phi$ & $\begin{array}{l}\text { Product Family } \\
\Psi\end{array}$ & \\
\hline Product typology & Toys & Thermometers & $\begin{array}{l}\text { Baby strollers, } \\
\text { car seats }\end{array}$ & High-tech engineered tools \\
\hline Product lifecycle & Medium & High & Medium & High \\
\hline Product variety & High & Low & High & Low \\
\hline $\begin{array}{l}\text { Innovation cycle } \\
\text { lead time (design- } \\
\text { to-deliver) }\end{array}$ & 9 months & 24 months & 9-12 months & Not disclosed \\
\hline $\begin{array}{l}\text { New product } \\
\text { development rate }\end{array}$ & High & Low & High & Low \\
\hline Process change rate & Medium & Minimal & Medium & Fixed process to Minimal \\
\hline Innovation novelty & $\begin{array}{l}\text { Radical, } \\
\text { incremental }\end{array}$ & Incremental & $\begin{array}{l}\text { Radical, } \\
\text { incremental }\end{array}$ & Incremental \\
\hline $\begin{array}{l}\text { Innovation } \\
\text { practices }\end{array}$ & $\begin{array}{c}\text { NPD, NPL, PD, } \\
\text { PR, CI }\end{array}$ & NPL, PD, PR, CI & $\begin{array}{c}\text { NPD, NPL, PD, } \\
\text { PR, CI }\end{array}$ & $\mathrm{PR}, \mathrm{CI}$ \\
\hline Market & Growing & Medium & Growing & Mature \\
\hline Product lifecycle & \multicolumn{4}{|c|}{ Low $(<1$ year), Medium $(<2$ years $)$, High $(>2$ years $)$} \\
\hline Product variety & \multicolumn{4}{|c|}{$\begin{array}{l}\text { Low ( }<10 \text { variants per category), Medium ( }<20 \text { variants per category), High ( }>20 \text { variants } \\
\text { per category) }\end{array}$} \\
\hline NPD rate & \multicolumn{4}{|c|}{$\begin{array}{l}\text { Low ( }<10 \text { offerings per year), Medium ( }<20 \text { offerings per year), High ( }>20 \text { offerings per } \\
\text { year) }\end{array}$} \\
\hline $\begin{array}{l}\text { Innovation } \\
\text { practices }\end{array}$ & \multicolumn{4}{|c|}{$\begin{array}{l}\text { NPD: New product development, NPL: New product launch, PD: Product design, PR: } \\
\text { Product restyling, CI: Continuous improvement }\end{array}$} \\
\hline
\end{tabular}


Figure 3. A reflection on Fisher's (1997) model.

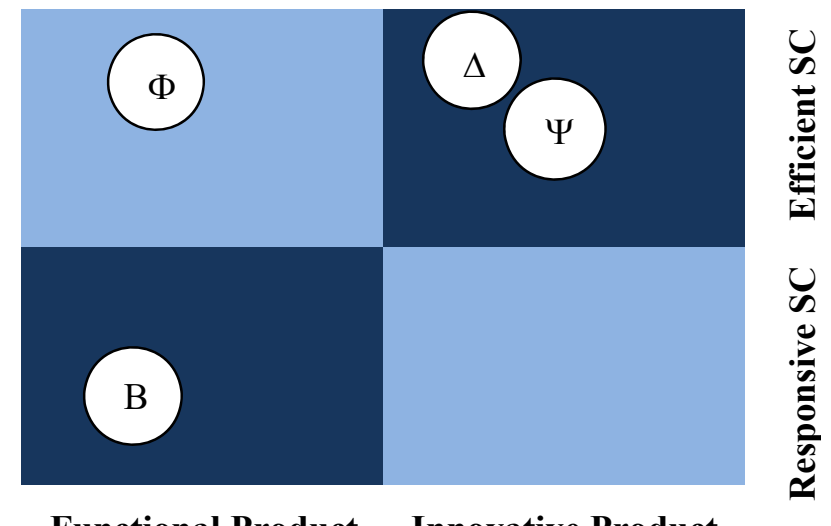

Functional Product Innovative Product 
Table 6. Process and product innovation practices interact with supply chain configuration settings.

\begin{tabular}{|c|c|c|c|c|c|c|c|}
\hline \multirow[t]{2}{*}{ Context } & \multirow{2}{*}{$\begin{array}{l}\text { Innovation } \\
\text { Practices }\end{array}$} & \multicolumn{4}{|c|}{ Impact on Supply Chain Configuration } & \multirow[t]{2}{*}{ Strategy } & \multirow[t]{2}{*}{ Sample Evidence from Groups Interviews } \\
\hline & & OPR & SND & DND & COL & & \\
\hline \multirow{4}{*}{ 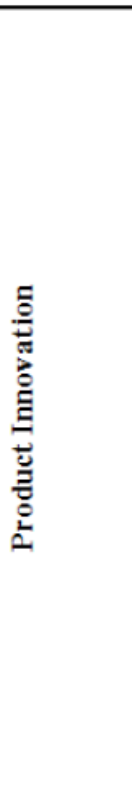 } & NPD & $\begin{array}{l}\text { - Decreasing lead times } \\
\text { - Personnel training }\end{array}$ & $=$ & $=$ & $\uparrow$ & \multirow[t]{4}{*}{$\begin{array}{l}\text { Firms demonstrate } \\
\text { higher flexibility and } \\
\text { readiness for change } \\
\text { management. }\end{array}$} & $\begin{array}{l}\text { "we renew our product range very often" } \\
\text { "human resources [is] the major cost and our } \\
\text { goal is to maintain a team of people always } \\
\text { available and able to do many different } \\
\text { products, to maintain as stable as possible the } \\
\text { number of workers" } \\
\text { "No we don't involve the distributors. It's only } \\
\text { an internal analysis" }\end{array}$ \\
\hline & NPL & $=$ & $=$ & $=$ & $\uparrow$ & & $\begin{array}{l}\text { "we defined a strategy of change andwe have } \\
\text { some open projects ready, and some new } \\
\text { projects to be open in the future in order to } \\
\text { improve the general performance of the } \\
\text { supply chain" }\end{array}$ \\
\hline & PD & $=$ & $=$ & $=$ & $=$ & & $\begin{array}{l}\text { "We have also a lot of restyling of the } \\
\text { products that means to change the decoration. }\end{array}$ \\
\hline & PR & $=$ & $=$ & $=$ & $\uparrow$ & & $\begin{array}{l}\text { to change the packaging, to change some } \\
\text { small features of the product and we have a } \\
\text { wide number of this second kind of } \\
\text { innovations." }\end{array}$ \\
\hline \multirow{2}{*}{ 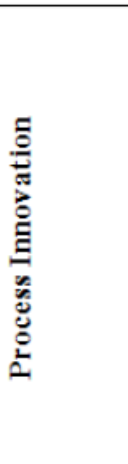 } & CI & $\begin{array}{l}\text { - Production unit } \\
\text { transformation } \\
\text { - Focus on improving quality, } \\
\text { production line efficiency, } \\
\text { equipment utilisation, } \\
\text { operational planning, }\end{array}$ & $=$ & $=$ & $\uparrow$ & \multirow[t]{2}{*}{$\begin{array}{l}\text { - Enhanced internal } \\
\text { coordination within the } \\
\text { company. } \\
\text { - Continuous } \\
\text { improvement projects } \\
\text { are compromised from } \\
\text { inter-functional teams. }\end{array}$} & $\begin{array}{l}\text { "The process innovation is for sure has [a] } \\
\text { strong impact on the supply chain because of } \\
\text { in terms of service, in terms of the production } \\
\text { capacity, [the] complexity of handling the } \\
\text { product, in terms of complexity of [the] range } \\
\text { of products." }\end{array}$ \\
\hline & NPI & $\begin{array}{l}\text { inventory optimisation } \\
\text { (EOQ), space optimisation, } \\
\text { warehouse centralisation. }\end{array}$ & $=$ & $=$ & $\uparrow$ & & $\begin{array}{l}\text { "We are launching this year an activity } \\
\text { concerning the raw materials. To analyse } \\
\text { with our suppliers better condition in terms of } \\
\text { mean ordering quantity of the raw materials } \\
\text { and in terms of handling the inventory" }\end{array}$ \\
\hline
\end{tabular}


Investigated innovation

Practices

SC configuration
NPD: New product development, NPL: New product launch, PD: Product design, PR: Product restyling, CI: Continuous improvement, NPI: New process introduction, P: Intellectual property and patents

OPR: Operations, SND: Supply network design, DND: Distribution network design, Log: Logistics, COL: Collaboration Unchanged: $=$

Increase: $\uparrow$ 